\title{
Evaluation of the use of plantain starch as a natural coagulant for the removal of colour and turbidity in water for human consumption
}

\author{
Angel Villabona ORTíz $Z^{1}$ \\ Candelaria Tejada Tovar ${ }^{1}$ \\ RODRIGO ORTEGA TORO ${ }^{1}$ \\ Marta Millán ANÍBAL ${ }^{1}$ \\ NATALiA LiCONA DAGER ${ }^{1}$
}

\section{Abstract}

Aim. To evaluate the effect on $\mathrm{pH}$, removal of turbidity and colour, using plantain starch as a natural coagulant, extracted by wet and basic route, in a sample of synthetic water. Materials and methods. The starch was extracted by placing the pre-treated biomass in contact with water or a $\mathrm{NaOH}$ solution for $20 \mathrm{~h}$ at $18{ }^{\circ} \mathrm{C}$, and then separating by filtration. The efficiency in the removal of turbidity and colour was carried out using a jug test, varying the initial concentration of coagulant and the stirring rate. Results. It was found that the starch obtained by the wet route presented a higher level of turbidity reduction compared to that obtained with $\mathrm{NaOH}$, reaching an efficiency of $94.6 \%$; using $150 \mathrm{mg} / \mathrm{L}$ of coagulant and $40 \mathrm{rpm}$, and having a better performance than the synthetic coagulant aluminium sulphate $\left(\mathrm{Al}_{2}\left(\mathrm{SO}_{4}\right)_{3}\right)$. Conclusions. The variable evaluated with the highest linear influence is the combination of stirring rate and coagulant concentration. The use of plantain starch extracted by wet route is recommended for use in water treatment for human consumption, highlighting its nature as an advantage over $\mathrm{Al}_{2}\left(\mathrm{SO}_{4}\right)_{3}$.

Keywords: Colour, pH, Turbidity, Stirring rate, Natural coagulant.

1 Universidad de Cartagena. Cartagena, Colombia.

Autor de correspondencia: Tejada Tovar, C. (Candelaria): Universidad de Cartagena: Calle 30 No. 39 B - 192, Barrio Piedra de Bolívar. Teléfono: 3002290095. Correo electónico: ctejadat@unicartagena.edu.co
Historia del artículo:

Artículo recibido: 28-X-2019/ Aprobado: 15-I-2020

Disponible online: 15 de enero de 2020

Discusión abierta hasta septiembre de 2021 


\section{Evaluación del uso de almidón de plátano como coagulante natural para la remoción de color y turbidez en agua para consumo humano}

\section{Resumen}

Objetivo: Evaluar el efecto sobre el pH, remoción de turbidez y color, usando almidón de plátano como coagulante natural, extraído por vía húmeda y básica, en una muestra de agua sintética. Materiales y métodos: El almidón se extrajo colocando la biomasa pre-tratada en contacto con agua y/o una solución de $\mathrm{NaOH}$ durante $20 \mathrm{~h}$ a $18^{\circ} \mathrm{C}$, y luego separando por filtración. La eficiencia en la remoción de turbidez y color, se realizó mediante prueba de jarras variando la concentración inicial de coagulante y la velocidad de agitación. Resultados: Se encontró que el almidón obtenido por vía húmeda presentó un nivel de reducción de turbidez más elevado respecto al obtenido con NaOH, alcanzándose una eficiencia del 94.6\%; usando $150 \mathrm{mg} / \mathrm{L}$ de coagulante y $40 \mathrm{rpm}$, y teniendo un mejor comportamiento que el coagulante sintético sulfato de aluminio $\left(\mathrm{Al}_{2}\left(\mathrm{SO}_{4}\right)_{3}\right)$. Conclusiones: La variable evaluada con la mayor influencia lineal es la combinación de la velocidad de agitación y concentración de coagulante. Se recomienda el uso de almidón de plátano extraído por vía húmeda para su uso en tratamiento de aguas para consumo humano, resaltando como ventaja su naturaleza frente al $\mathrm{Al}_{2}\left(\mathrm{SO}_{4}\right)_{3}$.

Palabras Clave: Color, pH, Turbidez, Velocidad de agitación, Coagulante natural.

\section{Avaliação do uso de amido de banana como coagulante natural para remoção de cor e turbidez na água para consumo humano}

\section{Resumo}

Objetivo. Alvo. Avaliar o efeito no pH, remoção de turbidez e cor, utilizando amido de banana como coagulante natural, extraído por via úmida e básica, em uma amostra de água sintética. Materiais e métodos. 0 amido foi extraído colocando a biomassa pré-tratada em contato com água ou uma solução de $\mathrm{NaOH}$ por $20 \mathrm{~h}$ a $18^{\circ} \mathrm{C}$ e depois separando por filtração. A eficiência na remoção de turbidez e cor foi realizada utilizando um teste de jarro, variando a concentração inicial de coagulante e a taxa de agitação. Resultados. Verificou-se que o amido obtido pela via úmida apresentou maior nível de redução de turbidez em relação ao obtido com NaOH, atingindo uma eficiência de 94,6\%; utilizando 150 mg/L de coagulante e $40 \mathrm{rpm}$ e com melhor desempenho que o sulfato de alumínio coagulante sintético $\left(\mathrm{Al}_{2}\left(\mathrm{SO}_{4}\right)_{3}\right)$. Conclusões. A variável avaliada com a maior influência linear é a combinação da taxa de agitação e da concentração de coagulante. Recomenda-se o uso de amido de banana extraído por via úmida no tratamento da água para consumo humano, destacando sua natureza como vantagem sobre o $\mathrm{Al}_{2}\left(\mathrm{SO}_{4}\right)_{3}$.

Palavras chave: Cor, pH, Turbidez, Taxa de agitação, Coagulante natural.

\section{Introduction}

Access to water with sanitary conditions for human consumption is essential for the health of consumers, and their final characteristics will depend on its origin (groundwater or surface water) and the potabilization treatment. Coagulation is a physicalchemical process to reduce the repulsive potential of the electric double layer of colloids using coagulants as metallic, polyelectrolytes and polymers. As a result, colloidal particles begin to develop and then agglomerate into larger particles or flocs (Sillanpää et al., 2018). The potabilization process consists of treating water for human consumption, which implies low costs, with easily operable installations. Generally, the system has a desander, flocculator, flocculator-sedimentador, filters and storage reserves (Pantoja-Espinosa et al., 2015).

There are different types of coagulants such as metallic salts, natural coagulants from plants rich in polysaccharides, proteins (Shamsnejati et al., 2015) and 
polyelectrolytes (Donato et al., 2006) (Salehizadeh et al., 2018). Normally, polymeric flocculants and inorganic coagulants have been used; these are are expensive, and generally consist of metal salts of synthetic origin, which affects the bodies of water due sludges are arranged without prior treatment (Kamar, Abdul Aziz and Ramli, et al., 2015). Despite, its effectiveness it has been found large amounts of inorganic ions on effluents, which fall the shelf life-time of the equipment owing to corrosion, fouling and clogging (Gao et al., 2009).

In this sense, starch is a natural coagulant alternative to minimise the harmful impacts caused by traditional coagulants. Starch has a low cost, renewable nature and environmentally friendly (Choy, Prasad and $\mathrm{Wu}$ et al., 2016). Gelatinised starch increases the viscosity of aqueous solutions, and it promotes the elimination of turbidity (Zhu, 2015).

Starch and its derivatives have been shown to be very useful for flocculation of ultrafine mineral particles and iron metals (Trujillo et al., 2014). Several researchers have used natural coagulants from alum and rice starch (Teh et al., 2014), calcium alginate (Arcila y Peralta, 2016), modified starches (López-Vidal et al., 2014), starch with alum and poly-aluminium chloride (Choy, Prasad and Wu et al., 2016). They found that the use of coagulants of natural origin is a viable alternative for their use in the clarification of surface waters, which represents a sustainable option for water treatment managers as opposed to inorganic coagulants. Therefore, the objective of the present study was to use plantain starch as a natural coagulant, in order to remove turbidity and colour present in a water sample by varying the agitation rate and concentration of the coagulant.

\section{Materials and Methods}

\subsection{Experimental design}

The present investigation used an experimental design of response-surface of central composite type. Two independent variables were evaluated (agitation rate (rpm) and coagulant concentration (mg/L)) with two variation levels (30 and $40 \mathrm{rpm}$ ). The dependent variables were $\mathrm{pH}$, colour (Platinum-Cobalt Scale [Pt/Co]) and turbidity (Nephelometric turbidity units [NTU]), and the intervening variables were centrifugation time (min), centrifugation rate $(1500$ rpm), cooling time (20 h) and sample concentration $(0.5 \mathrm{Kg} / \mathrm{L})$. During the experimentation, Merck brand analytical grade reagents were used.

\subsection{Starch extraction}

The starch extraction was done using $1000 \mathrm{~g}$ of plantain, it were peeled and sliced for subsequent washing with distilled water to eliminate impurities. Then $500 \mathrm{~g}$ were immersed in a solution of $0.25 \% \mathrm{NaOH}$ by weight and $500 \mathrm{~g}$ in water; both mixtures were cooled to $4 \stackrel{\circ}{\circ} \mathrm{C}$ for $20 \mathrm{~h}$, and then liquefied for $1 \mathrm{~min}$. After the maceration process, starch-rich products were obtained and filtered separately. The filtrates were centrifuged at $1500 \mathrm{rpm}$ for $10 \mathrm{~min}$. The centrifuged material was adjusted to neutral $\mathrm{pH}$ using a $2 \mathrm{M} \mathrm{HCl}$ solution and centrifuged again at the same conditions. Finally, the starch was dried and ground (Maniglia and Tapia, 2016).

\subsection{Turbid water preparation}

The synthetic turbid water was elaborated by dispersion of $0.3 \mathrm{~g}$ of bentonite in $800 \mathrm{~mL}$ of deionised water. This solution was mixed for $1 \mathrm{~h}$ at $200 \mathrm{rpm}$, and subsequently was left $21 \mathrm{~h}$ at rest for a hydration process. Then, it was diluted in $1.9 \mathrm{~L}$ of deionised water, and resulting dispersion has a turbidity of 32.3 NTU (Canepa et al., 2004; López-Vidal et al., 2014).

\subsection{Turbidity removal test}

The tests to remove turbidity and colour were performed by putting in contact the turbid water sample with the starch extracted in the jar test equipment at $200 \mathrm{rpm}$ for $1-2 \mathrm{~min}$. The agitation rate was reduced to 20-40 rpm for $15 \mathrm{~min}$, the mixture was left to repose, and an aliquot was taken to measure turbidity (NTU), colour $(\mathrm{Pt} / \mathrm{Co})$ and $\mathrm{pH}$ of the solution.

\subsection{Statistical anallysis}

The data analysis was carried out by software STATGRAPHICS centurion XVI, through an analysis of variance ANOVA that allowed separating the variations of the diverse factors that affect a dependent variable with a degree of effect 1 .

\section{Results and Discussion}

\subsection{Turbidity Removal Tests}

Two samples of starch were obtained from the extraction using $\mathrm{NaOH}$ and water. The dry weight of the 
samples was 38 and $35.5 \mathrm{~g}$ respectively. Subsequently, jar tests were performed, and the effect of the coagulant dose and agitation rate on the $\mathrm{pH}$ of the raw water samples was evaluated.

The $\mathrm{pH}$ was inversely proportional to the concentration of the coagulant, and the agitation rate does not significantly affect the $\mathrm{pH}$ of the samples (Figure 1).

It can be seen that the samples treated at $40 \mathrm{rpm}$ reveal a similar tendency in $\mathrm{pH}$ from the beginning (7.67-7.69) until the end (6.84-6.81), for the coagulant extracted with water and $\mathrm{NaOH}$, respectively. On the other hand, the coagulant extracted with water at 30 rpm had a pH from 7.76 to 6.81 . At last, the coagulant extracted with $\mathrm{NaOH}$ at $30 \mathrm{rpm}$ has the highest initial $\mathrm{pH}$ (7.96), and their final $\mathrm{pH}$ was similar to the others (6.89). The $\mathrm{pH}$ is a main parameter in coagulationflocculation process, due it can change the surface charge of the coagulant and/or contaminant; then, the starch obtained in the present study and used as natural coagulant is stable over a wide $\mathrm{pH}$ range and its use in real waters samples is recomended (Daverey, Tiwari and Dutta et al., 2018; Paredes et al., 2018).

Regarding the colour reduction of plantain starches, the colour value was 10 on the PlatinumCobalt scale (Table 1) for all the samples. Plantain starch did not affect the colour of water solutions. This result can be considered positive. Starch does not add colour to the raw water sample after the test. These results are within the $\mathrm{pH}$ range of 6.0-8.5 established by Shamsnejati et al., (2015) where the effected of $\mathrm{pH}$ on colour is not significant for the removal of dye from a textile wastewater model.

TABLE 1. TESTS OF COLOUR ON THE PLATINUM-COBALT SCALE

\begin{tabular}{|c|c|c|c|c|}
\multirow{2}{*}{ Starch } & \multirow{2}{*}{ Agitation (rpm) } & \multicolumn{4}{|c|}{$\begin{array}{c}\text { Coagulant concen- } \\
\text { tration (mg/L) }\end{array}$} \\
\cline { 2 - 5 } & & 125 & 187.5 & 250 \\
\hline Plantain $\mathrm{NaOH}$ & 30 & 10 & 10 & 10 \\
\cline { 2 - 5 } & 40 & 10 & 10 & 10 \\
\hline Plantain $\mathrm{H}_{2} \mathrm{O}$ & 30 & 10 & 10 & 10 \\
\cline { 2 - 5 } & 40 & 10 & 10 & 10 \\
\hline
\end{tabular}

The behaviour of turbidity concerning the coagulant dose and agitation rate during the jar test using plantain starch extracted with $\mathrm{NaOH}$ and water (Figure 2) were evaluated.

The coagulant concentration has a significantly positive effect on the removal of turbidity. Starch extracted with water ( 30 and $40 \mathrm{rpm}$ ) exhibits the best results. Turbidity was reduced more effectively, reaching a removal rate of $94.6 \%$ using $250 \mathrm{mg} / \mathrm{L}$ coagulant concentration and $40 \mathrm{rpm}$. This behaviour can be explained by the presence of amylopectin in the starch structure due to its electrolytic nature, which is a branched distribution of the proteins that compose it, and would trap in its structure, as was reported in literature (Trujillo et al., 2014).

\section{Figure 1. Effect of coagulant concentration and agitation rate on $\mathrm{pH}$}

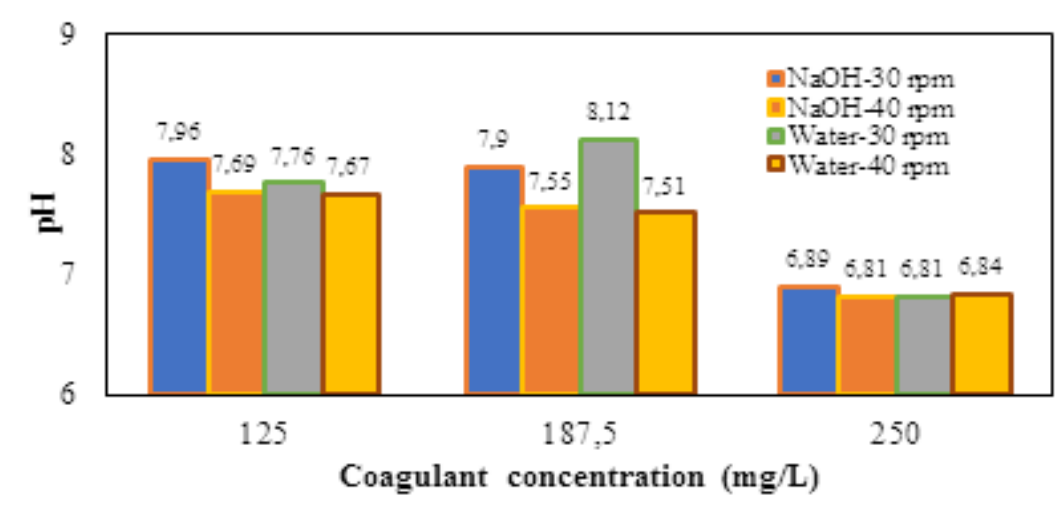


Figure 2. Effect of the agitation rate and concentration of coagulant on the removal of turbidity using plantain starch as coagulant

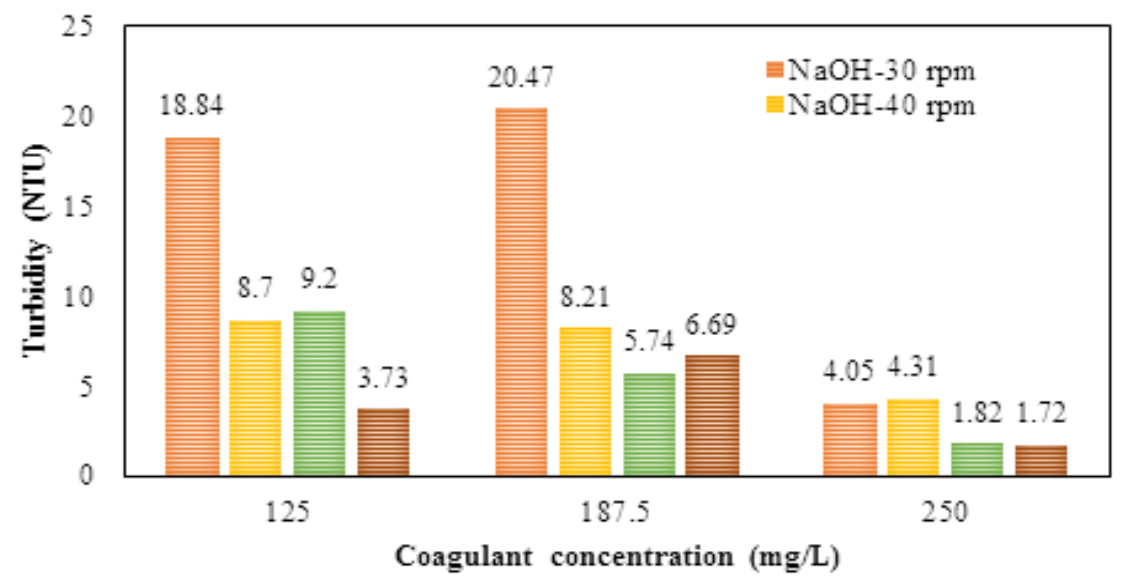

Figure 3. Effect of coagulant concentration and agitation rate on the $\mathrm{pH}$ of $\mathrm{Al}_{2}\left(\mathrm{SO}_{4}\right)_{3}$

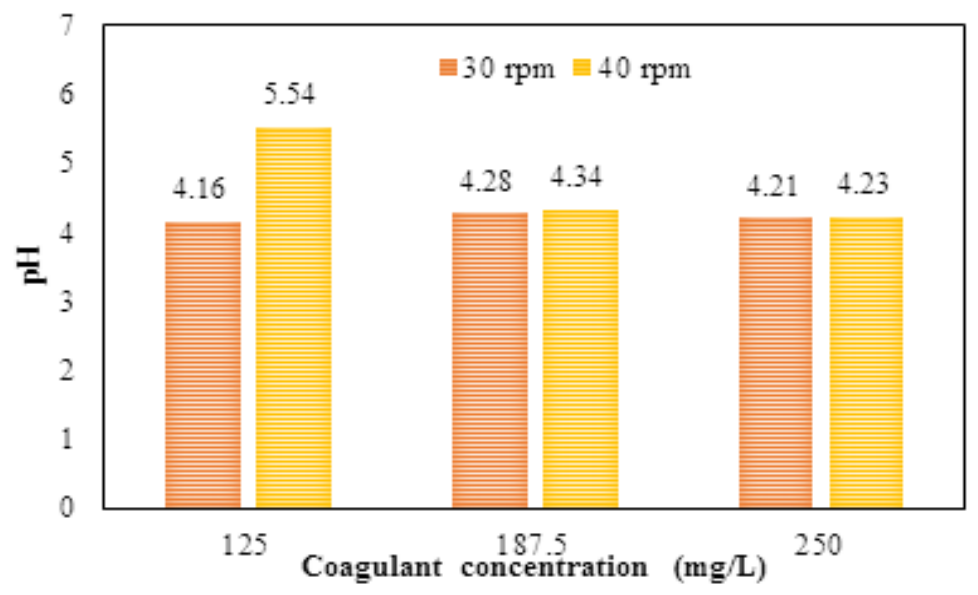

Figure 4. Effect of coagulant dose and agitation speed on turbidity removal using $\mathrm{Al}_{2}\left(\mathrm{SO}_{4}\right)_{3}$

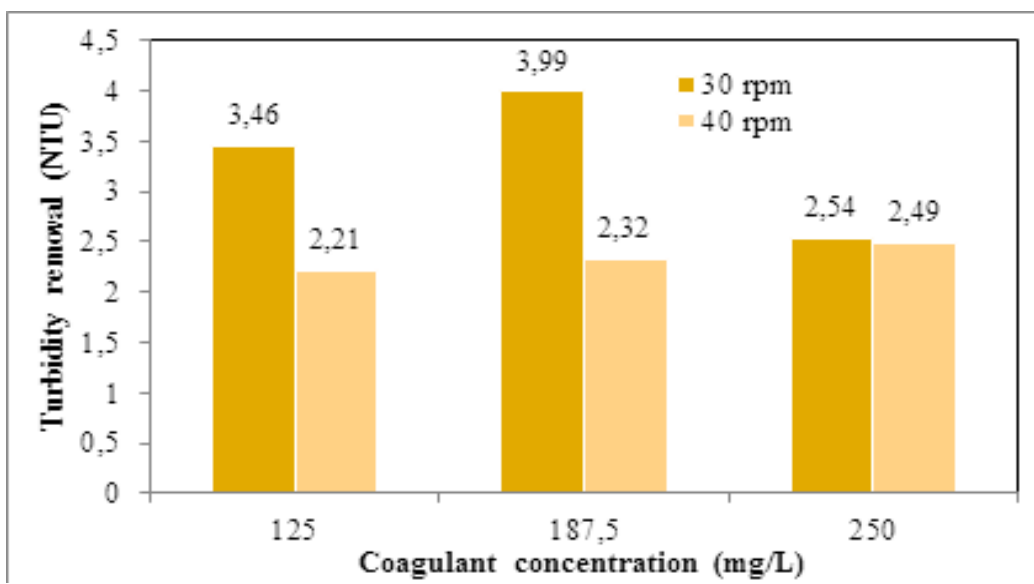


$\mathrm{Al}_{2}\left(\mathrm{SO}_{4}\right)_{3}$ was used as a synthetic coagulant to compare with the plantain starch extracted with $\mathrm{NaOH}$ and water. Figure 4 shows the results obtained from the turbidity measurement of raw water samples after a jug test using aluminium sulphate $\left(\mathrm{Al}_{2}\left(\mathrm{SO}_{4}\right)_{3}\right)$ as a coagulant.

Comparing the obtained results (Figure 1, Figure 3 and Figure 4), the residual $\mathrm{pH}$ values obtained with the natural coagulants extracted from the plantain were higher than those obtained with the synthetic coagulant. These results are like those reported by Ganjidoust et al., (1997), a natural coagulant (chitosan) had the better effect than synthetic coagulants (HE and PEL) eliminating up to $90 \%$ of the colour and $70 \%$ of organic carbon. This phenomenon can be explained due to the high rate of formation of flocs of excellent characteristics during the process, by the electrolytic nature of the natural coagulant tested, which contributes to the appropriate and rapid sedimentation by the consistency and weight of the flocculated particles (Paredes et al., 2018).

Table 2 shows the colour values on PlatinumCobalt scale using $\mathrm{Al}_{2}\left(\mathrm{SO}_{4}\right)_{3}$ as a coagulant. In all treatment at different concentrations and agitation rates, the colour was constant (10 units). Same results were obtained with the starch. According to Colombian regulation for drinking water, obtained results are admissible because the colour should be lesser than 15 units when a coagulant dosage of $250 \mathrm{mg} / \mathrm{L}$ is used (Resolution 2115, 2007).

\begin{tabular}{|c|c|c|c|}
\hline \multirow[t]{2}{*}{ Agitation (rpm) } & \multicolumn{3}{|c|}{$\begin{array}{c}\text { Coagulant concentration } \\
(\mathrm{mg} / \mathrm{L})\end{array}$} \\
\hline & 125 & 187.5 & 250 \\
\hline 30 & 10 & 10 & 10 \\
\hline 40 & 10 & 10 & 10 \\
\hline $\begin{array}{c}\text { Range required by } \\
\text { Resolution } 2115 \text { of } 2007\end{array}$ & \multicolumn{3}{|c|}{$<15$} \\
\hline
\end{tabular}

\subsection{Statistical anallysis}

Statistical analysis was performed using an ANOVA analysis of variance, as shown in Table 3 , which indicates that the coagulant concentration has a confidence level of 95.0 being significantly influential on the process.

TABLE 3. ANALYSIS OF VARIANCE FOR PH
\begin{tabular}{|c|c|c|c|c|c|c|c|c|c|c|}
\hline & \multicolumn{7}{|c|}{ Extracted with $\mathrm{NaOH}$} & \multicolumn{5}{c|}{ Extracted with water } \\
\hline Source & $\begin{array}{c}\text { Sum of } \\
\text { squares }\end{array}$ & D.F. & $\begin{array}{c}\text { Middle } \\
\text { Square }\end{array}$ & F-Reason & P-value & $\begin{array}{c}\text { Sum of } \\
\text { squares }\end{array}$ & D.F. & $\begin{array}{c}\text { Middle } \\
\text { Square }\end{array}$ & F- Reason & $P$-value \\
\hline A: Stirring rate & 0.0816 & 1 & 0.0816 & 1.12 & 0.368 & 0.019 & 1 & 0.0192 & 0.32 & 0.611 \\
\hline $\begin{array}{c}\text { B: Coagulant } \\
\text { Concentration }\end{array}$ & 0.950 & 1 & 0.950 & 13.00 & 0.0366 & 1.22 & 1 & 1.221 & 20.27 & 0.0205 \\
\hline Total error & 0.219 & 3 & 0.0731 & & & 0.180 & 3 & 0.060 & & \\
\hline Total (corr.) & 1.251 & 5 & & & & 1.421 & 5 & & & \\
\hline
\end{tabular}

TABLE 4. ANALYSIS OF VARIANCE FOR PERCENTAGE OF TURBIDITY REMOVAL OF POSTHARVEST PLANTAIN STARCH

\begin{tabular}{|c|c|c|c|c|c|c|c|c|c|c|}
\hline \multirow{2}{*}{ Source } & \multicolumn{5}{|c|}{ Extracted with $\mathrm{NaOH}$} & \multicolumn{7}{c|}{ Extracted with water } \\
\cline { 2 - 13 } & $\begin{array}{c}\text { Sum of } \\
\text { squares }\end{array}$ & D.F. & $\begin{array}{c}\text { Middle } \\
\text { Square }\end{array}$ & F- Reason & P-value & $\begin{array}{c}\text { Sum of } \\
\text { squares }\end{array}$ & D.F. & $\begin{array}{l}\text { Middle } \\
\text { Square }\end{array}$ & F-Reason & P-value \\
\hline A: Stirring rate & 41.343 & 1 & 41.343 & 0.72 & 0.457 & 77.688 & 1 & 77.688 & 8.34 & 0.063 \\
\hline $\begin{array}{c}\text { B: Coagulant } \\
\text { Concentration }\end{array}$ & 7.263 & 1 & 7.263 & 0.13 & 0.745 & 1.625 & 1 & 1.625 & 0.17 & 0.7043 \\
\hline Total error & 171.358 & 3 & 57.119 & & & 27.953 & 3 & 9.3178 & & \\
\hline Total (corr.) & 219.965 & 5 & & & & 107.267 & 5 & & & \\
\hline
\end{tabular}


For the analysis of $\mathrm{pH}$ variance, it was obtained that the concentration of coagulants extracted with water and $\mathrm{NaOH}$ had a P-value lower than 0.05 . This fact indicates that this variable affects the $\mathrm{pH}$, on the contrary to the agitation rate (P-value higher than 0.05 ) in both forms of extraction. The Durbin-Watson statistic (DW) showed that there was no serial autocorrelation since the P-value was higher than 0.05 .

Table 4 shows the ANOVA analysis for the percentage of turbidity removal, finding that none of the effects has a P-value less than 0.05 indicating that these variables and their correlations are not statistically incident on the process.

As for the variance of the turbidity percentage, the two variables (agitation rate and coagulant concentration) and the extraction with $\mathrm{NaOH}$ had a $\mathrm{P}$-value greater than 0.05. It indicates that none of these effects has an incidence on the turbidity percentage. On the other hand, the agitation rate obtained a P-value lesser than 0.05 for the coagulant extracted with water. The Durbin-Watson statistic (DW) proved that there was no serial autocorrelation since the P-value was higher than 0.05 .

\section{Conclusion}

The plantain starch tested did not contribute odour, flavour and colour to the raw water, it was also highlighted because the $\mathrm{pH}$ was maintained in the acceptable range so that the coagulationflocculation process was given satisfactorily. Under the conditions established when performing the jar test, the percentages of turbidity removal most of the cases were higher than $70 \%$, using doses of coagulants similar to conventional synthetic coagulants. Starch extracted with water being the most efficient for the removal of turbidity, the variable with the highest linear influence being the combination of agitation rate and concentration of coagulant, it is showing better behaviour regarding turbidity removal than the commercial aluminium sulphate coagulant.

\section{Acknowledgements}

The authors express their gratitude to the Universidad de Cartagena for supporting this work.

\section{References}

Arcila, H. R.; Peralta, J. J. (2016). Agentes naturales como alternativa para el tratamiento del agua. Revista Facultad de Ciencias Básicas, 11(2), Junio, pp. 136-153. http:// dx.doi.org/10.18359/rfcb.1303

Canepa, L.; Maldonado, V.; Barrenechea, A.; Aurazo, M. (2004). Tratamiento de agua para consumo humano: Plantas de filtración rápida. Manual I: Teoría. Tomo II, Lima: CEPCI, pp. 83 - 100.

Choy, S.Y.; Prasad, K.N.; Wu, T.Y.; Raghunandan, M.E.; Ramanan, R.N. (2016). Performance of conventional starches as natural coagulants for turbidity removal. Ecological Engineering, 94, Septiembre, pp. 352-364. https://doi.org/10.1016/j.ecoleng.2016.05.082

Daverey, A.; Tiwari, N.; Dutta, K. (2018). Utilization of extracts of Musa paradisica (banana) peels and Dolichos lablab (Indian bean) seeds as low-cost natural coagulants for turbidity removal from water. Environmental Science and Pollution Research, November, pp. 1-7. https://doi.org/10.1007/s11356-018-3850-9

Donato, N.R.; Mendoza, R.N.; Rodríguez, M.Á.; Mijares, E.M. (2006). Obtención de sulfato de quitosano y su aplicación en el proceso de coagulación-floculación de suspensiones coloidales aniónicas de caolinita. Revista Iberoamericana de Polímeros, 7(3), Agosto, pp. 145-161.

Ganjidoust, H.; Tatsumi, K.; Yamagishi, T.; Gholian, R.N. (1997). Effect of synthetic and natural coagulant on lignin removal from pulp and paper wastewater. Water Science and Technology, 35(2-3), pp. 291-296. https:// doi.org/10.1016/S0273-1223(96)00943-2

Gao, Q.; Zhu, X.H.; Mu, J.; Zhang, Y.; Dong, X.W. (2009). Using Ruditapes philippinarum conglutination mud to produce bioflocculant and its applications in wastewater treatment. Bioresource Technology, 100(21), Julio, pp. 4996-5001.https://doi.org/https://doi.org/10.1016/j. biortech.2009.05.035

Kamar, W.I.S.; Abdul Aziz, H.; Ramli, S.F. (2015). Removal of suspended solids, chemical oxygen demand and color from domestic wastewater using sago starch as coagulant. Applied Mechanics and Materials, 802, Octubre,pp. 519-524. https://doi.org/10.4028/www. scientific.net/AMM.802.519

López-Vidal, R.; Laines-Canepa, J.R.; Hernández-Barajas, J.R.; Aparicio-Trápala, M.A. (2014). Evaluación de almidones de malanga (Colocasia esculenta) como agentes coadyuvantes en la remoción de turbiedad en procesos de potabilización de agua. Revista Mexicana de Ingeniería Química, 13(3), Diciembre, pp. 855-863, 2014.

Maniglia, B.C.; Tapia, D.R. (2016). Isolation and characterization of starch from babassu mesocarp. Food Hydro- 
colloids, 55, Abril, pp. 47-55. https://doi.org/10.1016/j. foodhyd.2015.11.001

Ministerio De La Protección Social, Ministerio De Ambiente Vivienda Y Desarrollo Territorial. Por medio de la cual se señalan características, instrumentos básicos y frecuencias del sistema de control y vigilancia para la calidad del agua para consumo humano. Resolución 2115 de 2007. Bogotá, D.C.: Ministerio de la Protección Social; Ministerio de Ambiente Vivienda y Desarrollo Territorial.

Pantoja-Espinoza, J.C.; Proal-Nájera, J.B.; García-Roig, M.; Cháirez-Hernández, I.; Osorio-Revilla, G.I. (2015). Eficiencias comparativas de inactivación de bacterias coliformes en efluentes municipales por fotólisis (UV) y por fotocatálisis $\left(\mathrm{UV} / \mathrm{TiO}_{2} / \mathrm{SiO}_{2}\right)$. Caso: depuradora de aguas de Salamanca, España. Revista Mexicana de Ingeniería Química, 14(1), Enero-Marzo, pp. 119-135.

Paredes, C.M.D.; Carranza, M.M.H.; Albornoz, J.I.F.; Salazar, R.A.P.; Jamanca, N.F.A. (2018). Efectividad de especies naturales como ayudantes de Coagulación , para la clarificación de aguas turbias en épocas de avenidas en caseríos y centros poblados de Huaraz y Callejón de Huaylas. Aporte Santiaguino, 11(2), Enero, pp.299-310. 10.32911/as.2018.v11.n2.583

Salehizadeh, H.; Yan, N.; Farnood, R. (2018). Recent advances in polysaccharide bio-based flocculants. Biotechnology Advances, 36(1), Enero-Febrero, pp. 92-119. https://doi. org/10.1016/j.biotechadv.2017.10.002

Shamsnejati, S.; Chaibakhsh, N.; Pendashteh, A.R.; Hayeripour, S. (2015). Mucilaginous seed of Ocimum basilicum as a natural coagulant for textile wastewater treatment. Industrial Crops and Products, 69, Julio, pp. 40-47. https://doi.org/10.1016/j.indcrop.2015.01.045

Sillanpää, M.; Ncibi, M.C.; Matilainen, A.; Vepsäläinen, M. (2018). Removal of natural organic matter in drinking water treatment by coagulation: a comprehensive review. Chemosphere, 190, Enero, pp. 54-71. https:// doi.org/10.1016/j.chemosphere.2017.09.113

Teh, C. Y.; Wu, T.Y.; Juan, J.C. (2014). Optimization of agroindustrial wastewater treatment using unmodified rice starch as a natural coagulant. Industrial Crops and Products, 56, Mayo, pp. 17-26. https://doi. org/10.1016/j.indcrop.2014.02.018

Trujillo, D.; Duque, L.F.; Arcila, J.S.; Rincón, A.; Pacheco, S.; Herrera, O.F. (2014). Remoción de turbiedad en agua de una fuente natural mediante coagulación/floculación usando almidón de plátano. Revista Ion, 27(1), EneroJunio, pp. 17-34.

\section{PARA CITAR ESTE ARTÍCULO / TO REFERENCE THIS ARTICLE / PARA CITAR ESTE ARTIGO /}

Villabona Ortíz, A.; Tejada Tovar, C.; Ortega Toro, R.; Millán Aníbal, M.; Licona Dager, N. (2020). Evaluation of the use of plantain starch as a natural coagulant for the removal of colour and turbidity in water for human consumption. Revista EIA, 17(33) enero-junio, Reia33013 pág. 1-8. Disponible en: https://doi.org/10.24050/reia.v17i33.1359 